\title{
Assessment of the Implementation Practice of Emergency Planning Regulations Dedicated to the Rail Transportation of Dangerous Goods
}

\author{
KÁTAI-urBÁN Lajos - HOrVÁTH Hermina ${ }^{1}$
}

\begin{abstract}
These days it is especially important, and a complex task at the same time, to protect human health and the environment at a high level. One of the most important elements of this protection policy is industrial safety, highlighted by the major accidents of recent years. Industrial safety embraces four special fields: the supervision of dangerous plants, the control of the transportation of dangerous goods, the protection of critical infrastructure and the prevention of nuclear accidents. In our essay we dedicate our attention firstly to the assessment of the international and national legal regulations concerning the emergency planning of the railway's dangerous activities. Secondly, the main goal of this article is to analyse the implementation of the above mentioned regulations by the operators of Hungarian railway infrastructure.
\end{abstract}

\section{Introduction}

The special safety requirements of the transportation of dangerous goods are stipulated in legal regulations in Hungary, and we are bound to follow them by strict international rules. In terms of the transportation of dangerous goods by road, rail, inland waterways and air transportation, they all have their respective regulations.

In spite of the strict international and national regulations there were numerous accidents in Hungary and abroad as well, highlighting that in addition to prevention we have to be prepared in all cases to be able to manage and control the occurring event in a professional way, and we have to make our best efforts to reduce potential consequences and their effects to a minimum. In order to implement this in practice we have to apply a comprehensive emergency management plan. In consideration of the functioning of our country as a Eu member state, we have to streamline continuously the Hungarian norms, technical and methodological requirements corresponding to the expectations of the European regulations related to the prevention of emergencies, and within this that of major accidents involving dangerous substances.

The vulnerability assessment and emergency management planning activities applied in case of establishments using dangerous substances shall be carried out in case of marshalling yards as well. During the transportation, storage of dangerous substances and for the sake of the safety of installations we have to consider the appearance of the aforementioned risks and we have to fulfil in any and all cases the requirements stipulated in the directive 96/82/EC, on the control of major accident hazards involving dangerous substances (hereinafter: Seveso II. directive).

In line with the description above, in our essay we will analyse the aspects of industrial safety in cases of rail transportation. In order to obtain an overall picture of the topic it is necessary to review

1 Both authors: Institute of Disaster Management, of the National university of Public Service, Budapest, Hungary 
the basis of international and national legal regulations related to dangerous goods transported by rail, the system of national emergency management planning and the company regulations of the Hungarian State railways Plc. (Magyar Államvasutak Zrt.) (hereinafter: MÁV Zrt.) as the operator of the rail tracks system in Hungary, as related to the emergency management planning of marshalling yards used for dangerous goods.

\section{Evaluation of major accidents that happened in Hungary and world- wide in the presence of dangerous goods}

In the world there were numerous industrial accidents with major consequences that went beyond the site borders and endangered neighbouring settlements as well. One of them was the environment pollution caused by dioxin 1976 in Seveso, Italy, another the massive poisoning caused by methyl-isocyanine released at the site of union Carbide in Bhopal, India in 1984 (see Table 1.). ${ }^{2}$

\begin{tabular}{|c|c|l|}
\hline year & Location & \multicolumn{1}{c|}{ Consequences } \\
\hline 1976 & Seveso, Italy & $\begin{array}{l}\text { July 1976 in North-Italy, in the course of an accident at a chemical plant of } \\
\text { Hoffman La roche in Givaudan (close to the small town, Seveso next to } \\
\text { Milan) producing pesticides, dioxin was released into the atmosphere. The } \\
\text { poisoning caused by the dioxin cloud resulted in the emergency slaughter } \\
\text { of some 100,000 cattle. The accident did not take a toll on human lives, but } \\
\text { several hundreds of people had to be evacuated. }\end{array}$ \\
\hline 1984 & Bhopal, India & $\begin{array}{l}\text { From the underground tank of the plant of union Carbide in Bhopal produc- } \\
\text { ing pesticides and polyurethane a highly toxic gas (methyl-isocyanine) was re- } \\
\text { leased. Within a short time some 400,000 people suffered harm, and poisoning } \\
\text { in different degrees. There were 3,135 fatalities. }\end{array}$ \\
\hline 1984 & $\begin{array}{l}\text { Mexico City, } \\
\text { Mexico }\end{array}$ & $\begin{array}{l}\text { On November 19, 1984 in Mexico City one of the gas tanks of the state- } \\
\text { owned oil company exploded. A high quantity of liquid gas was spilled, } \\
\text { causing fire, explosion and then several BLeVe-s. 400 people lost their lives } \\
\text { in the accident, more than 1,000 people were seriously injured, 300,000 inhab- } \\
\text { itants had to be evacuated from the surroundings of the establishment. }\end{array}$ \\
\hline
\end{tabular}

Table 1. Data of major industrial accidents $1 .^{3}$

Some of the major accidents affected not only the local community, but spread beyond the state boundaries into neighbouring countries, and potentially the states located on the downstream catchment area. It is enough to think of the event that happened in 1986 in the Sandoz factory in Switzerland or of the cyanide and heavy metal pollution in Nagybánya (Baia Mare) February 2000, which caused environmental damage in several countries in the rhine, Tisza and Danube rivers (see Table 2.).

Numerous international and national examples can be used to demonstrate events of the rail transportation of hazardous goods. In the following table the transportation data of some accidents related to the rail transportation of hazardous goods by rail that happened recently and aroused the attention of the media are listed (see Table 3.).

2 KÁTAI-urBÁN (2006)

3 Source: KÁTAI-urBÁN (2006) 
Kátai-Urbán Lajos - HorvátH Hermina: assessment of the implementation Practice of Emergency Planning...

\begin{tabular}{|c|c|c|}
\hline year & Location & Consequences \\
\hline 1986 & $\begin{array}{c}\text { Basel, } \\
\text { Switzerland }\end{array}$ & $\begin{array}{l}\text { Because of fire in the storage room of insecticides a high quantity of firewater } \\
\text { made its way into the sewer and then into the rhine and due to this during the next } \\
\text { days most of the fauna of the river was destroyed. An environmental disaster } \\
\text { polluted a } 500 \mathrm{~km} \text { long transboundary section of the rhine. }\end{array}$ \\
\hline 2000 & $\begin{array}{l}\text { Nagybánya } \\
\text { (Baia Mare), } \\
\text { romania }\end{array}$ & $\begin{array}{l}\text { The cyanide storage lake of the Aurul mining company is in the vicinity of Nagy- } \\
\text { bánya (Baia Mare), which was exposed to such a high water load that the badly } \\
\text { designed dam burst along a width of } 25 \mathrm{~m} \text { on January } 30,2000 \text {. At least } 100,000 \\
\mathrm{~m}^{3} \text { of highly toxic wastewater, containing at least } 120 \text { tons of cyanide (lethal doses } \\
\text { for } 2 \text { million people) was spilled. The toxic wave polluted the whole Hungarian } \\
\text { section of the Tisza river, and did not spare Voivodina and the Danube and the } \\
\text { Black Sea either. }\end{array}$ \\
\hline 2000 & $\begin{array}{c}\text { Borsabánya, } \\
\text { romania }\end{array}$ & $\begin{array}{l}\text { On March 10, } 2000 \text { in the morning hours there was a dam slide at the Novac } \\
\text { settlement storage basin owned by the romanian company romin in Borsabánya } \\
\text { because of the heavy rain. } 10-20 \text { thousand } \mathrm{m}^{3} \text { of pollution (containing lead, zinc and } \\
\text { copper) got via the river Visó into the Tisza river. }\end{array}$ \\
\hline 2005 & $\begin{array}{l}\text { Buncefield, } \\
\text { united } \\
\text { Kingdom }\end{array}$ & $\begin{array}{l}\text { On December 11, } 2005 \text { in the morning an oil storage facility exploded in Bunce- } \\
\text { field located to the north of London. The explosion damaged buildings within } \\
\text { a wide radius. Twenty tanks, with a storage capacity of } 14,000 \mathrm{~m}^{3} \text { each, burned } \\
\text { down. } 43 \text { were injured, there were no fatalities, at the same time } 2,000 \text { people had } \\
\text { to be evacuated for the night. }\end{array}$ \\
\hline 2005 & China & $\begin{array}{l}\text { On November 13, } 2005 \text { there was an explosion in the catchment area of the Songhoua } \\
\text { river in Csilin province, on the territory of the chemical plant } 380 \mathrm{~km} \text { from Harbin } \\
\text { (China), where some } 1,000 \text { tons of benzene made its way into the surface water and the } \\
\text { concentration of nitrobenzene was } 108 \text { times higher than the allowed level. In the large } \\
\text { city with four million inhabitants people panicked because of the } 80 \mathrm{~km} \text { pollut- ant spot } \\
\text { getting closer and this impacted the relationship between russia and China. } \\
\text { In China water consumption, in Russia fishing was prohibited by the authorities. An } \\
\text { attempt to neutralize the chemicals by means of active carbon took place. }\end{array}$ \\
\hline
\end{tabular}

Table 2. Data of major industrial accidents $2 .{ }^{4}$

\begin{tabular}{|c|c|l|}
\hline year & Location & \multicolumn{1}{c|}{ Consequences } \\
\hline 2012 & $\begin{array}{c}\text { Mosonma- } \\
\text { gyaróvár- } \\
\text { Bagolyvár }\end{array}$ & $\begin{array}{l}\text { On March 24, 2012 in the marshalling yard of Mosonmagyaróvár sulphuric acid } \\
\text { leaked from one of the wagons of a train consisting of 8 wagons. The accident did } \\
\text { not endanger inhabited areas, but for the duration of the emergency management } \\
\text { the area affected by the emergency was closed in a radius of 100 m. The cargo (57 } \\
\text { tons) of the wagon was transloaded into the empty tank of the establishment at } \\
\text { the destination, the dangerous substance that leaked into the area between the rail } \\
\text { tracks was neutralized. }\end{array}$ \\
\hline 2012 & $\begin{array}{l}\text { Máriabesnyö, } \\
\text { in the vicinity } \\
\text { of Bag }\end{array}$ & $\begin{array}{l}\text { On May 12, 2012 the last seven empty wagons of a freight train consisting of 42 } \\
\text { containers derailed. There was sulphuric acid in one container but nobody was in- } \\
\text { jured from the accident. The experts of the rail company and of the rescue organisa- } \\
\text { tions have restored the damage caused by the accident by May 14. }\end{array}$ \\
\hline 2012 & $\begin{array}{l}\text { In the vicinity } \\
\text { of Cegléd }\end{array}$ & $\begin{array}{l}\text { On December 11, 2012 a van transporting isotope capsules considered hazardous goods } \\
\text { crashed with a train in the vicinity of Cegléd. The van transported 25 kg of haz- ardous } \\
\text { goods, according to the papers of the vehicle, 192 pieces of isotope capsules were in a } \\
\text { small container. The container was damaged in the accident, but there was } \\
\text { no dangerous substance released into the atmosphere, as the capsules did not break. }\end{array}$ \\
\hline
\end{tabular}

Table 3. Data of railway accidents ${ }^{5}$ 
The events listed in the table aroused the attention of experts and the public because of their major consequences possibly directly threatening human health and life. However we can conclude from the experience of several near-misses (incidents) that every incident caused by technical defect of human error or external effect implies the possibility of the occurrence of major events and sometimes disasters. In our opinion, for the prevention of such events a high-level authority licensing, supervision and control system is required, in addition to the emergency management planning system ensuring the professional management of incidents that have already occurred.

\section{International and national legal regulation of the prevention of major accidents in disaster management}

The community-level integration of the prevention of industrial accidents looks back to a history of more than two decades, the Seveso directive undergoes some modifications and gets stricter and stricter every five years. In line with the european integration activity and the international obligations of the country the Hungarian Parliament and government has prepared regulations about the prevention of major industrial accidents. The effective date of the Hungarian regulations is January 1, 2002 and has been modified significantly twice (2006 and 2012).

Our country undertook as of January 1, 2002 to integrate the Seveso II. Directive into the legal regulations of Hungary and to implement the provisions specified in the same text before the date of the Eu accession. The directive (2003) took effect in 2006 in Hungary with the objective of preventing major industrial accidents involving hazardous substances, mitigating its effects on man and environment, and ensuring a high-level of protection in a consequential and efficient way on the territory of the European Community. ${ }^{6}$ The uN ECE Convention on Industrial Accidents introduced simultaneously with the Seveso regulation handles the cross border effects and consequences of industrial accidents potentially occurring in an upper tier establishment using dangerous substances identified according to the Seveso II. Directive.

The Directive excludes marshalling yards mentioned in Article 4 from the scope of application, however the Council Directive No. 96/49/EC ${ }^{7}$ designates interim temporary storage at marshalling yards as "a station necessary in the course of transportation".

One of the triggers of the changes in legal regulations between 2010-2011 serving the improvement and development of the disaster management system was the strengthening and establishment of more efficient protection against major accidents involving dangerous goods. Recent events, like the industrial catastrophe caused by the dam bursting of the mining waste reservoir in the outskirts of Ajka on October 4, 2010 or major accidents that happened in establishments processing hazardous wastes, in meat processing establishments, in establishments using chlorine and in establishments handling pyrotechnic products have contributed to the changes of the disaster management regulations concerning the legal field of industrial safety.

Act 2011 CXXVIII. on disaster management and on the amendment of individual, related acts (disaster management act) and the regulation 219/2011 (X. 20.) on the protection against major accidents involving dangerous substances (hereinafter: implementation regulation) - in line with the Seveso II. Directive - clearly define the scope of activities covered by the regulations, the tasks of the authorities related to the activities, the tasks of the operators of dangerous

6 VASS (2006)

7 KOSSA (2011) 
establishments, of the government and municipalities related to the prevention of and preparation for major accidents, and to the emergency management of the same and also the obligations related to information made public.

There are new tasks and competences of industrial safety specified in the disaster management act and in the implementing regulations listed below:

1. Extension of the rights of the disaster management authorities (licensing, supervision, inspection) over establishments below the lower threshold level,

2. Introduction of new legal institutions (emergency management fine, administration service fee);

3. Disaster management tasks of the protection of critical infrastructure;

4. Making the authority activities and procedures more simple and efficient;

5. extension of the controlling and fining authorisations of the disaster management authority with regard to the transportation of dangerous goods by rail, air and inland waterways. ${ }^{8}$

These new tasks and competences and their efficient and successful implementation requires the extension of the previously operated structure of industrial safety and the establishment of an organisation for industrial safety and code of procedure.

The last modification of the Seveso II. Directive was necessary among others to adapt the Seveso regulation to the CLP regulation (regulation 1272/2008/EC of the European Parliament and Council on the classification, labelling and packaging of materials and blends). The directive 2012/18/Eu of the European Parliament and Council (Seveso III directive) on the management of the hazards of major accidents involving dangerous substances and on the modification and later cancelation of directive 96/82/EC has been adopted on July 4, 2012. The Seveso III. Directive shall be introduced by the Eu member states and thus also Hungary by the end of May 2015.

\section{Emergency management planning system of plants}

The paramount goal of emergency management planning in Hungary is to create a standardized system of documents by means of the identification and analysis of various endangering factors, containing disaster management tasks and actions with the allocated human resources, finances and technical means. The rules of the preparation of the plans, those obliged to prepare emergency plans, the content of the plans and the order of approval are described in the Government Decree 234/2011 (XI. 10.) on disaster management and on the execution of act CXXVIII. of 2011 on the amendment of related individual acts (Act on Disaster Management).

Emergency management planning helps in every case minimize consequences, where an accident causing serious damage to the environment or to the public can occur. It integrates the order, implementation of disaster management tasks and actions into a standard system, by allocating the necessary human resources, funds and technical means.

The levels of emergency management planning are:

a) Settlement emergency plan,

b) Workplace emergency plan,

c) The summarized plan of the local organisation of the official emergency management organisation,

d) regional (county or capital) emergency management plan,

e) Central (national level) emergency management plan.

$8 \operatorname{KOSSA}(2011)$ 
Included in the plans are first the conditions of emergency management in the course of the dangerous situation, the actions to be taken within a short time after the accident and the key decisions that can significantly influence the success of the mitigating actions. ${ }^{9}$ On this basis it is clear that the deep understanding of the probable scenario of the events and of the counter-measures is very useful for those who can play a role in the emergency response and damage control.

In the sense of the IV-th chapter of the Disaster Management Act. the operator of the establishment dealing with dangerous substances prepares an internal emergency plan in order to eliminate the consequences of the dangers described in the safety report (upper tier site) or in the safety analysis (lower tier site).

The provisions of the safety analysis and safety report regarding the prevention and control of major accidents related to dangerous substances shall be elaborated in such a way as to ensure the high-level protection of human health and the environment. To this end it also has to cover the concept regarding the resources and tools, organisation and management system required for an efficient emergency management system.

The safety documentation that includes the internal emergency plan as well, is revised and if necessary modified by the operator in case of an establishment dealing with dangerous substances in the cases stipulated in the execution regulations (government decrees), at least every five years. The operator sends the results of the revision and the modified safety analysis or report to the disaster management authority. The authority decides on the basis of the safety report or analysis received about the extension of the permit or about requiring prevention or consequence mitigation measures. ${ }^{10}$

The aforementioned actions serving the high-level protection of the public do not appear directly in the legal regulation guaranteeing the safety of rail transport.

\section{Infrastructure and safety regulation of the rail transport of hazardous goods in Hungary}

The European Council and Parliament has adopted the so called TEN plans of transportation in 1996, with the objective of establishing a standardized road, rail, sea and air transportation infrastructure within the territory of the Eu. One of the cornerstones of the railway policy of the Eu is that during the years to come a high volume of dangerous goods, if possible, shall be shifted to railway. Within the rail transport of goods the ratio of the transportation of dangerous goods is between 19-20\%. Compared to road transportation a major advantage is the more economic transportation over a long distance, while weather conditions and traffic risks are less relevant than on the road. The evaluation of the hazardous goods transported in Hungary, based on the goods' classes, shows that railway transportation is focussed mainly on the transportation of inflammable materials, gases and corrosive materials. The ratio of toxic materials and explosives is lower, compared to the aforementioned materials. ${ }^{11}$

9 VArGA 2005

10 2011. évi CXXVIII. törvény a katasztrófavédelemről és a hozzá kapcsolódó egyes törvények módosításáról (Act 2011/CXXVIII. on disaster management and related individual acts.)

11 Veszélyes áruk vasúti forgalmának megoszlása áruosztályok szerint. In NAGy Zsolt ed.: Veszélyes áru Évkönyv 2011 Magyarország. Biztonsági Tanácsadók Nemzetközi Szakmai Egyesülete. Budapest, 2012, p. 69. (Split of dangerous goods in rail transport by goods classes. In: International Professional Association of Safety Consultants, yearbook of Dangerous goods 2011, Hungary.) 
There is a difference of opinion among experts as to whether the rail or road transport of hazardous goods represents a higher degree of danger for those living in the area concerned. In terms of transport mode preferences there are no special transportation authority measures or provisions in the territory of the Eu member states. In general it can be stated that it is mainly economic and logistic considerations that play a role in the selection of individual transportation modes. However it is sure that in cases of transportation of significant volumes over a long distance (more than 200 $\mathrm{km}$ ) rail transportation services and facilities are preferred.

In the territory of marshalling yards as temporary storage installations, there are toxic, flammable and explosive materials, and in cases of major accidents involving these substances the effects harming human health can spread over several hundreds of meters or even kilometres.

Special safety conditions regarding the transportation of dangerous goods are specified in legal regulations in Hungary. We are bound by interstate agreements to follow these regulations in international transportation. International regulations are strict and in most cases also highly up-to-date. They reflect the international cooperation of experts from industry, environmental protection and safety, which is necessary because of the international nature of trade and transportation and because of the standard safety level desired. In terms of the transportation of dangerous goods there is an independent regulation for railway transportation, the "regulation concerning the International Carriage of Dangerous Goods by rail" (hereinafter: rID), which is annex "C" to the Convention concerning International Carriage by rail (COTIF) C, and which was concluded on June 3, 1999 in Vilnius.

The amendment of the Disaster Management Act that took effect on January 1, 2012 and of the related sector-specific act (Rail Transportation Act CLXXXIII of 2005.) created the legal background for the disaster management organisation to inspect the rail transportation of dangerous goods as an independent authority and can if needed impose fines and take other actions to avoid emergency situations.

By virtue of the authorization, based on the amended sector-specific acts, the Government Decree No. 312/2011. (XII. 23.) on the rules of the standard procedure regarding the inspection of the rail and inland waterways transportation of dangerous goods and on imposing fines and on the amount of fines that can be imposed in case of anomalies and on the general rules of authority tasks related to fining, has been issued in order to describe the implementation in detail. ${ }^{12}$

On the basis of the first result of the application of the regulation concerning the inspection of dangerous goods transported by rail, that took effect recently, it can be established that there were 747 so-called rID inspections performed by the disaster management authorities in 2012 and the disaster management experts have inspected a total number of 10,095 railway vehicles. Among these there were 5,176 railway vehicles transporting dangerous goods. The inspecting authorities found 194 railway containers to be defective or not in line with the regulations. ${ }^{13}$ It is evident, from the above mentioned control data, that with regard to industrial safety, inspections performed by the disaster management authorities and prevention and preparation measures (obligations) introduced by those of authority after the inspections in case of irregularities and omissions are absolutely needed.

12 BOGNÁr-VASS-KOZMA (2012)

13 Veszélyes áruk vasúti szállitásának ellenőrzése 2012. MI NDGDM, Annual report 2012. (Inspection of the rail transportation of hazardous goods.) 


\section{Practice of internal emergency response planning at marshalling yards}

In 2003, with the help of the European Commission the decision of the uIC International union of railways "Guideline for the preparation of internal emergency response plans at marshalling yards" ${ }^{14}$ were published. The guideline is considered, on the basis of the rID regulation, as a basic document in the area of emergency response planning. ${ }^{15}$

The provisions of rID shall be applied in national and international transportation as well. In the sense of the effective legal regulations in Hungary regarding the transportation of dangerous goods official disaster management organisations do not have licensing and supervising tasks and competences, which applies also to the internal emergency response plans to be prepared for marshalling yards according to the Chapter 1.11. of rID regulations.

MÁV Zrt. has prepared, according to its internal regulations based on the rID regulation, the internal emergency response plans of the four major marshalling yards (Záhony, Miskolc, Budapest-Ferencváros and Szolnok) handling dangerous goods. Later, in the order No. 33/2009. (V.1.) of the director-general this area was newly regulated, covering in detail the emergency management tasks of the company in case of accidents occurring in the course of the transportation of dangerous goods or in response to the impact of dangerous goods released during an extraordinary event, endangering man and environment. In line with the decision uIC $201 \mathrm{E}$, as of 2003, an internal emergency response plan shall be prepared for marshalling yards involved in the transportation of dangerous goods. Internal emergency response plans shall be revised every year and shall be updated as needed. In case of new marshalling yards the emergency response plans shall be prepared before the start of the function, allowing the simultaneous modification of the external emergency response plan prepared by the local authorities. ${ }^{16}$

In case of marshalling yards already in operation, following the changes of the internal emergency response plan the external emergency response plan shall be revised and modified if needed. These documents shall always be up-to-date, usable at any time and have to contain all the information the response team might need.

The emergency response plans of the marshalling yard falls within the competence of the marshalling yard operator. In order to prepare the internal emergency management plan and to have it tested, railway companies shall cooperate with the operator of the railway infrastructure. The plan covers the complete response of the operator in connection with the accident occurring with a dangerous substance at the marshalling yard, and shall describe in detail, how the operator shall prepare the persons working in the area affected by the emergency, and how to control, limit and mitigate the effects of any emergency. The plan describes as well, how external organisations sent to the location of emergency and those working at the site could help, how the work of external organisations is helped, while ensuring the safety of the persons affected. In order to implement the contents of the emergency management plan the persons in charge shall be identified by their respective names, positions and all those responsible persons shall be identified, who supervise

14 UIC Nemzetközi Vasútegylet „Útmutató a belső veszélyelhárítási tervek készítésére a rendezőpályaudvarokon" c. döntvénye, 2003. (International railway Association, decision "Guideline for the preparation of internal emergency plans at marshalling yards")

15 A veszélyes áruk nemzetközi vasúti szállításáról szóló előírás (RID), 2012. (Regulation concerning the International Carriage of Dangerous Goods by rail.)

16 33/2009. (V. 1. MÁV ért. 15.) VIG order of the director-general about the tasks of MÁV Zrt. in disaster management and civil protection. 
and coordinate emergency response and mitigation measures. ${ }^{17}$ The damage control, emergency management of an accident is the task of the maintenance company of MÁV Zrt. within the frame of its services.

The plans shall be based on the individual needs of the marshalling yards, on the danger situations that can be identified and on the management actions of such danger situations, and shall cover all major accident situations and scenarios that can be foreseen. The plan is based on the identified hazards of the accidents that have already occurred, where always the worst case scenario shall be considered. ${ }^{18}$

One of the most important units to be set up when an accident occurs and to be considered when preparing the emergency management plan is the emergency management centre. Emergency response operations are steered and coordinated from here. The centre liaises with the response team, the local authorities, hospitals, local health authorities, with the management of the rail company and with the media.

After the transformation of the organisational structure of MÁV Zrt. the tasks of rail track system operation, railway safety, transportation, accident response and control are split among MÁV Zrt. as rail track system operator and the railway companies. As part of the cooperation between the Ministry of the Interior, the National Directorate-General for Disaster Management and MÁV Zrt., within a common (pilot) project in 2011 an internal emergency management model plan has been prepared for the marshalling yards in the region of Záhony near the ukrainian border, which can be the basis for the preparation of the plans of other marshalling yards. ${ }^{19}$

\section{Conclusion}

All in all it can be stated that in terms of marshalling yards the disaster management authority, for lack of authorization by relevant Hungarian legal regulations, at the present on the basis of a cooperation agreement with the MÁV group, can offer, instead of authority supervision, professional assistance to the operator of the rail tracks for the sake of the improvement of the emergency management activities.

However within the excellent professional cooperation between the disaster management and railway system operators the international and national methodological guides required for the preparation of the emergency response plans and the results of the common pilot project (sample plans) are available.

All these actions create suitable conditions for the preparation of the internal emergency plans of establishments in case of all marshalling yards and afterwards the elaboration of the external emergency plans of settlements, and after the provision of the conditions of their application for ensuring the high-level safety of the public.

17 219/2012. (X. 20.) regulation about the protection against major accidents involving dangerous goods

18 SZAKÁL et al. (2012)

19 Veszélyes áruk fuvarozása-Módszertani útmutató a rendezö pályaudvarok veszélyelhárítási tervezési feladatainak végrehajtásához. BM OKF, 2004. (Transportation of hazardous goods - Methodological guideline for the implementation of the emergency management planning at marshalling yards.) 


\section{References}

A veszélyes áruk nemzetközi vasúti szállításáról szóló elöírás (RID), 2012. (Regulation concerning the International Carriage of Dangerous Goods by rail.)

BOGNÁr Balázs - VASS Gyula - KOZMA Sándor (2012): A BM OKF Országos Iparbiztonsági Főfelügyelőség szakterületeinek bemutatása. In: Új Magyar Közigazgatás. 2012/6. p. 19-27. (Pre- sentation of the special fields of the National Chief Inspectorate for Industrial Safety MI NDGDM)

KÁTAI-urBÁN Lajos (2006): Az ipari balesetek országhatáron túli hatásai elleni védekezés alkalmazá- si feltételeinek értékelése és fejlesztése. Doktori (PhD) értekezés. Budapest. (Evaluation and develop- ment of the conditions of the application of the protection against the cross border effects of industrial accidents. Phd dissertation.)

KOSSA György (2011): Iparbiztonság - feladatok és kihívások a jövő védelmében. In: Védelem- Katasz- trófa-Tüz- És Polgári Védelmi Szemle. 18. (6) pp. 49-50. (Industrial safety - tasks and challenges to protect the future)

SZAKÁL Béla - CIMEr Zsolt - KÁTAI-urBÁN Lajos - SÁrOSI György - VASS Gyula (2012): Iparbiztonság I. Veszélyes anyagok és súlyos baleseteik az iparban és a szállitásban. Korytrade Kft., Budapest. (Industrial safety I. Dangerous goods and major accidents in industry and transportation.)

UIC Nemzetközi Vasútegylet „Útmutató a belső veszélyelhárítási tervek készítésére a rendezőpályaud- varokon” c döntvénye, 2003. (International railway Association, decision "Guideline for the prepa- ration of internal emergency plans at marshalling yards")

VArGA Imre (2005): A veszélyes anyagokkal kapcsolatos súlyos balesetek elleni megelözési és véde- kezési tevékenység rendszere. Doktori $(\mathrm{PhD})$ értekezés. Budapest. (System of prevention from and protection against major accidents involving dangerous goods. Phd dissertation.)

VASS Gyula (2006): A településrendezési tervezés helye és szerepe a veszélyes anyagokkal kapcsolatos súlyos ipari balesetek megelözésében. Doktori $(\mathrm{PhD})$ értekezés. Budapest. (The place and role of the land use plan in the prevention of major industrial accidents involving dangerous goods. Phd disser- tation.)

Veszélyes áruk fuvarozása - Módszertani útmutató a rendezö pályaudvarok veszélyelháritási tervezési feladatainak végrehajtásához. BM OKF, 2004. (Transportation of hazardous goods - Methodological guideline for the implementation of the emergency management planning at marshalling yards.)

Veszélyes áruk vasúti forgalmának megoszlása áruosztályok szerint. In NAGy Zsolt ed.: Veszélyes áru Évkönyv 2011 Magyarország. Biztonsági Tanácsadók Nemzetközi Szakmai Egyesülete. Budapest, 2012, p. 69. (Split of dangerous goods in rail transport by goods classes. In: International Professional Association of Safety Consultants, yearbook of Dangerous goods 2011, Hungary.)

Veszélyes áruk vasúti szállitásának ellenörzése 2012. MI NDGDM, Annual report 2012. (Inspection of the rail transportation of hazardous goods.) 